\title{
A STUDY OF THE PROPHYLACTIC EFFECTIVENESS OF SEVERAL 8-AMINOQUINOLINES IN SPOROZOITE-INDUCED VIVAX MALARIA (CHESŚON STRAIN) ${ }^{1}$
}

\author{
By RALPH JONES, JR.,2 BRANCH CRAIGE, JR.,2 ALF S. ALVING, C. MERRILL \\ WHORTON,2 THEODORE N. PULLMAN, 2 AND LILLIAN EICHELBERGER
}

(From the Malarial Research Unit, Department of Medicine, University of Chicago)

(Received for publication December 23, 1946)

In 1931 and 1933, James ( 1 to 3 ) reported the first work on the prophylactic activity of the standard antimalarial agents, quinine, quinacrine (atabrine), and pamaquin (plasmochin), in Plasmodium vivax malaria under controlled conditions. He demonstrated that neither quinine nor quinacrine, given as prophylactic agents in therapeutic doses, prevented malarial infection. Extensive experience in the field ( 4 to 6 ) has corroborated this finding.

James (3) also reported that when pamaquin was given in amounts approaching the maximum tolerated dose for eight days, starting the day before sporozoite inoculation, none of the subjects developed malaria. Smaller doses protected only a few of the subjects.

However, in 1944, Feldman, Packer, et al. (7),

1 This investigation was carried out under contract, recommended by the Committee on Medical Research, between the Office of Scientific Research and Development and the University of Chicago. The studies were planned in cooperation with the Panel on Clinical Testing of Antimalarials of the Board for the Coordination of Malarial Studies. This work was further aided by the participation of Army Medical officers assigned to the project by the Surgeon General.

Through a cooperative arrangement between Professor Clay G. Huff and Dr. Frederick Coulston, Department of Bacteriology and Parasitology, and the Malarial Research Unit, Department of Medicine, the former group bred Anopheles quadrimaculatus mosquitoes, supervised their infection and the inoculation of volunteers, and determined the intensity of infection in the salivary glands of the mosquitoes. The latter group assumed the responsibility for clinical care of patients studied by both groups.

The authors express their thanks to the Malaria Study Section of the National Institute of Health for editorial assistance and for arrangements in regard to the publication of this paper. They are also grateful to the Abbott Laboratories, E. I. du Pont de Nemours and Company, Inc., E. R. Squibb and Sons, Eli Lilly and Company, Sharp and Dohme, Inc., and Wyeth, Inc., for contributing toward the publication costs.

2 Formerly Captain, M.C., A.U.S. repeating the pamaquin observations of James, reported that in the $\mathrm{McCoy}$ strain of vivax malaria the same or slightly higher doses of pamaquin did not protect all of the subjects.

Because of the implication of these and other observations, that pamaquin has an extraordinary effect on the $P$. vivax parasite, an intensive study of pamaquin and its analogues was undertaken. We have conducted studies to determine whether pamaquin and other 8-aminoquinolines would prevent infection with the Chesson (Southwest $\mathrm{Pa}$ cific) strain of vivax malaria.

TABLE I

The chemical structure, toxicity in the monkey, and antimalarial activity in birds of pamaquin and three other 6-methoxy-8-aminoquinolines (18)

\begin{tabular}{|c|c|c|c|c|}
\hline \multirow{3}{*}{ Drug } & \multirow{3}{*}{$\begin{array}{c}\text { Aliphatic side chain in } \\
\text { 8-position }\end{array}$} & \multirow{3}{*}{$\begin{array}{l}\text { Com- } \\
\text { para- } \\
\text { tive } \\
\text { mon- } \\
\text { key } \\
\text { tox- } \\
\text { icity }\end{array}$} & \multirow{2}{*}{\multicolumn{2}{|c|}{$\begin{array}{c}\begin{array}{c}\text { Quinine } \\
\text { coefficient }\end{array} \\
\begin{array}{c}\text { Antimalarial } \\
\text { activity }\end{array}\end{array}$}} \\
\hline & & & & \\
\hline & & & $\begin{array}{l}\text { Chick } \\
\text { Gal- } \\
\text { lina- } \\
\text { ceum }\end{array}$ & $\begin{array}{c}\text { Duck } \\
\text { Lo- } \\
\text { phurae }\end{array}$ \\
\hline$\overline{\text { Pamaquin }}$ & 4-diethylamino-1-methylbutyl- & 1 & $10-40$ & 80 \\
\hline $\begin{array}{l}\text { SN-1,452 } \\
\text { SN-11,191 } \\
\text { SN-13,276 }\end{array}$ & $\begin{array}{l}\text { 3-aminopropylamino } \\
\text { 6-diethylaminohexylamino } \\
\text { 5-isopropylaminoamylamino }\end{array}$ & $\frac{1}{t}$ & $\begin{array}{r}40 \\
30 \\
100\end{array}$ & $\begin{array}{r}3 \\
100 \\
150\end{array}$ \\
\hline
\end{tabular}

The four compounds studied (pamaquin, $\mathrm{SN}$ $11,191, \mathrm{SN}-1,452$, and $\mathrm{SN}-13,276$ which is pentaquine) are all 6-methoxy-8-aminoquinolines. They differ from each other only in the structure of the aliphatic side-chain substituent of the 8amino group (Table I). These four compounds were selected for human testing because they had high antimalarial activity in avian infections and because their toxicity in the monkey was low and of the pamaquin type, which, in contradistinction to the plasmacid type of toxicity, is reversible (8). 


\section{METHODS AND PROCEDURES}

Details of the methods used in the drug-testing procedures are presented elsewhere (9). White, male, inmate volunteers with no history of previous malaria served as test subjects at Stateville Penitentiary. ${ }^{3}$

In order not to overlook a prophylactically effective drug by exhibiting the agent in insufficient dosage, an approximation of the maximum amount tolerated in man was administered. This dosage was calculated on the basis of toxicity in the monkey or in man when known. The regime used by James (1) in which the drug was given the day before inoculation, the day of inoculation, and for six days thereafter, was followed. In the patients to whom SN-1,452 and $180 \mathrm{mgm}$. per day of pentaquine $(\mathrm{SN}-13,276)$ were administered, the schedule was shortened because of serious toxicity. Because of their rapid disappearance from the plasma, the drugs were given in divided doses at four-hour intervals. All drug dosages are in terms of base. For example : $200 \mathrm{mgm}$. of the pamaquin naphthoate represents $90 \mathrm{mgm}$. pamaquin base.

The test and control subjects were inoculated by the bites of ten mosquitoes heavily infected with the Chesson strain of $P$. vivax. Since the penitentiary is in a nonendemic area, accidental reinoculation was no problem. The Chesson strain is characterized by the early appearance of the primary attack after prophylactic administration of suppressive drugs and by prompt relapse after therapy with non-curative drugs (10 to 12 ).

Thick films were made from capillary blood and examined for parasites at frequent and regular intervals throughout the follow-up period. Those subjects who developed malaria were hospitalized and treated with whatever drug regime was currently being used for therapeutic testing.

Blood was drawn daily about one hour after the 8 a.m. dose. The plasma concentrations were determined by the method of Brodie, Udenfriend and Taggart (13) modified as follows: $20 \mathrm{ml}$. of heptane and $0.5 \mathrm{ml}$. of iso-butyl alcohol were placed in a 60-ml. glass stoppered bottle. Ten ml of plasma and $10 \mathrm{ml}$. of $0.1 \mathrm{~N} \mathrm{NaOH}$ were added and the mixture shaken for 10 minutes. The mixture was then transferred to a 50-ml. centrifuge tube and centrifuged for five minutes. The water phase was aspirated and $15 \mathrm{ml}$. of the heptane phase was transferred to a 40-ml. glass-stoppered pointed centrifuge tube containing $0.5 \mathrm{ml}$. of coupling reagent (diazotized sulphanilic acid). The mixture was then shaken for five minutes and centrifuged. The heptane layer was removed by aspiration. Not less than $0.3 \mathrm{ml}$. of the water layer was transferred to a special microcuvette and the transmission read in a spectrophotometer (Coleman) at a wave length of 480 millimicra.

Hemoglobin and methemoglobin values were determined by the method of Wendel (14).

3 The studies reported in this paper would not have been possible except for the enthusiastic cooperation of the inmate volunteers and administrative officials of Stateville Penitentiary.
RESULTS

\section{Prophylactic tests}

Pamaquin, SN-11,191, and SN-1,452 were tested simultaneously in the early part of the study. Pentaquine was studied later.

Two of the five subjects who received pamaquin prophylactically developed fever and parasitemia promptly, 18 and 19 days after sporozoite inoculation (Table II). One subject developed a delayed primary attack 106 days after infection, and two volunteers have shown no evidence of

TABLE II

Prophylactic effect of four 6-methoxy-8-aminoquinolines

\begin{tabular}{|c|c|c|c|c|c|c|c|}
\hline Drug & $\begin{array}{l}\text { Daily } \\
\text { dose* }\end{array}$ & $\begin{array}{c}\text { Days } \\
\text { of } \\
\text { drug } \\
\text { admin.t }\end{array}$ & $\mid \begin{array}{c}\text { Num- } \\
\text { ber } \\
\text { of } \\
\text { sub- } \\
\text { jects }\end{array}$ & $\begin{array}{c}\text { Num- } \\
\text { ber } \\
\text { pro- } \\
\text { tected }\end{array}$ & $\begin{array}{c}\text { Fol- } \\
\text { low-up } \\
\text { pro- } \\
\text { tected } \\
\text { cases }\end{array}$ & $\begin{array}{c}\text { Parasitic } \\
\text { pre- } \\
\text { patent } \\
\text { period, } \\
\text { cases un- } \\
\text { protected }\end{array}$ & $\begin{array}{c}\text { Mean } \\
\text { plasma } \\
\text { concen- } \\
\text { tration }\end{array}$ \\
\hline Pamaquin & $\begin{array}{r}m g m . \\
90\end{array}$ & $1-1-6$ & 5 & 2 & \multirow{3}{*}{20} & $\begin{array}{c}\text { days } \\
19 \\
18 \\
106\end{array}$ & $\begin{array}{c}\text { gamma/ } \\
\text { liter } \\
80 \\
70 \\
90 \\
370 \\
80\end{array}$ \\
\hline SN-1,452 & 240 & $1-1-3$ & 3 & 2 & & 21 & \\
\hline SN-11,191 & 90 & $1-1-6$ & 3 & 2 & & 16 & $\begin{array}{l}120 \\
110 \\
100\end{array}$ \\
\hline Controls & \multicolumn{2}{|c|}{ None } & 4 & $\mathbf{0}$ & & 12 to 14 & \\
\hline SN-13,276 & 120 & $1-1-6$ & 5 & 4 & $\begin{array}{r}11 \\
11 \\
11 \\
9\end{array}$ & 22 & $\begin{array}{l}60 \\
50 \\
50 \\
50 \\
40 \\
\end{array}$ \\
\hline Controls & \multicolumn{2}{|c|}{ None } & 12 & o & & 12 to 19 & \\
\hline $\mathrm{SN}-13,276$ & 180 & $\begin{array}{l}1-1-6 \\
1-1-3 \\
1-1-2\end{array}$ & $\begin{array}{l}1 \\
2 \\
2\end{array}$ & $\begin{array}{l}1 \\
2 \\
2\end{array}$ & 9 & & $\begin{array}{l}40 \\
90 \\
60 \\
40 \\
80\end{array}$ \\
\hline Controls & \multicolumn{2}{|c|}{ None } & 10 & 0 & & 12 to 17 & \\
\hline
\end{tabular}

* Dose is in terms of the base weight.

$+1-1-6$ means drug administration the day before, the day of, and for six days after inoculation by the bites of ten mosquitoes.

malaria during the 20 months which have elapsed since they were infected. ${ }^{4}$ Two subjects who were treated with $\mathrm{SN}-11,191$ and two who were treated with $\mathrm{SN}-1,452$ have had no malaria during 20 months' observation (Table II). One subject

4 One subject showed two positive thick blood smears 362 days and 369 days after inoculation. Numerous negative smears and two negative sub-inoculations of $200 \mathrm{ml}$. of blood failed to substantiate the parasitemia. No fever developed. 
in each of the latter groups developed clinical malaria within three weeks after inoculation.

The four subjects who served as controls for the first three drugs developed clinical malaria 12 to 14 days after inoculation.

Pentaquine was tested for prophylactic activity in doses of $120 \mathrm{mgm}$. and $180 \mathrm{mgm}$. per day. One of the five volunteers who were treated with $120 \mathrm{mgm}$. developed fever and parasitemia 22 days after inoculation. The other four subjects have shown no evidence of malaria during the nine to 11 months which have elapsed since they were bitten by infected mosquitoes. The 12 control subjects who were inoculated on the same days developed clinical malaria in 12 to 19 days.

All of the five subjects who received $180 \mathrm{mgm}$. of pentaquine per day have been protected from malaria to date, nine months after inoculation, even though two of them received the drug for only two days, and two more for only three days, after the day of inoculation. The ten volunteers who served as controls for this experiment developed clinical malaria 12 to 17 days after inoculation.

It is obvious that pamaquin exhibited prophylactic activity against the Chesson strain of vivax malaria, but it was only a partial prophylactic agent under the conditions of these studies. The prophylactic action of pamaquin was shared by three related 8-aminoquinoline compounds.

One subject in the pamaquin test group consistently maintained a plasma drug concentration about four times that attained by the other men in his group. He was the first subject in the group to develop malaria. In the group tested with SN-11,191, the one subject who developed malaria was the man who had the highest mean plasma concentration of the drug. ${ }^{5}$ Otherwise there was no observable correlation between concentration of drug in the plasma and success of prophylaxis.

\section{Subsequent course of malaria in patients who were not protected by prophylactic treatment}

Of the 21 patients who were treated prophylactically with these four 8-aminoquinolines, only six developed malaria. The six patients served as

5 At the time these observations were performed, the method for determination of SN-1,452 was not available.
TABLE III

Results of treatment of the primary attdck in the six pa. tients whose primary attack occurred after prophylactic treatment

Treatment of primary attack

\begin{tabular}{|c|c|c|c|c|}
\hline Case & $\begin{array}{l}\text { Previous } \\
\text { prophylactic } \\
\text { drug }\end{array}$ & $\begin{array}{c}\text { Drug regime } \\
\text { during } \\
\text { primary } \\
\text { attack }\end{array}$ & $\begin{array}{l}\text { Result after } \\
\text { treatment } \\
\text { of primary } \\
\text { attack }\end{array}$ & $\begin{array}{l}\text { Relapse rate } \\
\text { of other } \\
\text { patients on } \\
\text { same thera- } \\
\text { peutic regime }\end{array}$ \\
\hline 1 & Pamaquin & $\mathrm{SN}-11,437$ & $\begin{array}{l}\text { No relapse } \\
\text { in } 18 \\
\text { months }\end{array}$ & 4 out of 4 \\
\hline 2 & Pamaquin & $\begin{array}{l}\mathrm{SN}-11,437 \\
\text { and } \\
\text { chloroquine } \\
(\mathrm{SN}-7618)\end{array}$ & $\begin{array}{l}\text { No relapse } \\
\text { in } 18 \\
\text { months }\end{array}$ & 4 out of 4 \\
\hline 3 & Pamaquin & $\begin{array}{l}\text { Pamaquin } \\
\text { (15 mgm./ } \\
\text { day) and } \\
\text { quinine }\end{array}$ & $\begin{array}{l}\text { No relapse } \\
\text { in } 14 \\
\text { months }\end{array}$ & 3 out of 4 \\
\hline 4 & $\mathrm{SN}-1,452$ & $\begin{array}{l}\mathrm{SN}-11,437 \\
\text { and quinine }\end{array}$ & $\begin{array}{l}\text { Prompt } \\
\text { relapse }\end{array}$ & 3 our of 4 \\
\hline \multirow[t]{2}{*}{5} & SN-11,191 & $\mathrm{SN}-11,191$ & $\begin{array}{l}\text { No relapse } \\
\text { in } 19 \\
\text { months }\end{array}$ & 4 out of 4 \\
\hline & $\begin{array}{l}4 \text { Controls } \\
\text { infected by } \\
\text { same mos- } \\
\text { quitoes as } \\
\text { above } \\
\text { patients }\end{array}$ & $\begin{array}{l}\text { Various } \\
\text { suppressive } \\
\text { drugs }\end{array}$ & Relapse & \\
\hline \multirow[t]{2}{*}{6} & $\mathrm{SN}-13,276$ & Quinine & $\begin{array}{l}\text { Delayed } \\
\text { relapse }\end{array}$ & 14 out of 16 \\
\hline & $\begin{array}{l}5 \text { Controls } \\
\text { infected by } \\
\text { same mos- } \\
\text { quitoes as } \\
\text { above } \\
\text { patients }\end{array}$ & $\begin{array}{l}\text { Various } \\
\text { suppressive } \\
\text { drugs }\end{array}$ & Relapse & \\
\hline
\end{tabular}

subjects in therapeutic tests at the time of their primary attacks. Each one was treated on a different drug regime with an antimalarial agent ineffective in preventing relapse in other cases (Table III). The one subject who was not protected by $\mathrm{SN}-1,452$ relapsed promptly after treatment of his primary attack, and the subsequent course of his malaria was not unusual. The four subjects who were not protected by pamaquin or $\mathrm{SN}-11,191$ have shown no evidence of malaria for the 14 to 19 months which have elapsed since the treatment of their primary attacks with non-curative drug regimes. The one patient who was not protected by $\mathrm{SN}-13,276$ given prophylactically, relapsed after quinine treatment of the primary attack but had a long latent period. 
The increased susceptibility of the primary attacks to drugs, after prophylactic treatment with 8 -aminoquinolines, is supported by results in two sets of controls. First, 32 out of 36 patients similarly treated for a clinical attack, but infected by different mosquitoes, relapsed. Second, all of the control subjects, who were inoculated by the same mosquitoes as were the groups who received prophylactic drugs, and who were later treated with known suppressive drugs, experienced the frequent and repeated relapses characteristic of Chesson infections. These two groups serve as controls, therefore, not only on the effectiveness of drugs but also on the degree of infectivity of the mosquitoes.

\section{TOXICITY}

Since in these studies drugs were administered in doses approaching the estimated maximum tolerated dose, toxicity was expected and found. The symptoms produced by the drugs, with a few exceptions, were qualitatively alike. Many of the patients suffered abdominal, usually epigastric, discomfort or pain, anorexia, nausea, and vomiting. The epigastric pain, which was most severe in several of the group on $180 \mathrm{mgm}$. of SN-13,276, extended into the retrosternal area, and caused enough tenderness to limit the respiratory excursion.

Cyanosis was noted when the methemoglobin exceeded 6 or 7 per cent of the total hemoglobin. The average total hemoglobin values fell slowly and gradually. The average loss of hemoglobin was 1.75 grams per $100 \mathrm{ml}$. of blood, the greatest loss being about the 12th to 14th day after the start of medication. The white counts were more erratic, both mild leucopenia and slight leucocytosis being observed.

Electrocardiograms showed in many cases a slight and transient diminution in the height of the T-waves.

Other laboratory observations, including urinalysis and tests for urine urobilinogen, cephalin flocculation, estimations of the non-protein nitrogen and the serum bilirubin, yielded normal values or negative results. Postural hypotension, which occurred in some cases receiving pentaquine therapeutically (15), was not noted in these subjects.
Drug fever appeared on the fourth to sixth day of treatment in all three subjects receiving $\mathrm{SN}$ 1,452 and in two of the five receiving $180 \mathrm{mgm}$. of pentaquine daily.

Because of drug fever or abdominal pain, the administration of the drugs was terminated in the three cases on $\mathrm{SN}-1,452$ and in four of the five on $180 \mathrm{mgm}$. of pentaquine prior to the scheduled end of treatment.

Although in individual cases a correlation was not always apparent, generally speaking, in groups of patients the degree of methemoglobinemia furnished a numerical guide not only to the amount of cyanosis, but also to the severity of other symptoms. The average per cent of hemoglobin converted to methemoglobin on the three consecutive days when methemoglobinemia was greatest is shown in Table IV.

TABLE IV

Methemoglobin formation during administration of several 8-aminoquinolines

\begin{tabular}{c|c|c}
\hline \hline Drug & $\begin{array}{c}\text { Daily dose } \\
\text { (base) }\end{array}$ & $\begin{array}{c}\text { Methemo- } \\
\text { globinemia }\end{array}$ \\
\cline { 2 - 3 } & $\begin{array}{c}\text { mgm. } \\
\text { Per cent of lotal } \\
\text { hemoglobix }\end{array}$ \\
Pamaquin & 90 & 11.7 \\
SN-1,452 & 240 & 10.3 \\
SN-11,191 & 90 & 9.6 \\
Pentaquine & 120 & 5.3 \\
Pentaquine & 180 & 11.0 \\
\hline
\end{tabular}

Inasmuch as most of the courses on $180 \mathrm{mgm}$. of pentaquine and all the courses of $\mathrm{SN}-1,452$ were terminated early, the methemoglobin percentages for these groups are probably lower than would have been the case had they been allowed to continue for the full eight days. Peak values for methemoglobinemia were commonly reached after seven days. The regime of $120 \mathrm{mgm}$. of pentaquine per day caused less methemoglobin formation than any of the other regimes. The subjective symptomatology was also less in this group.

\section{DISCUSSION}

In these investigations, drug administration was limited to six days after inoculation because it has been shown by subinoculation that trophozoites usually do not appear in the peripheral blood before the ninth day after the mosquito bites (4). James' eight-day regime, with inoculation on the 
second day, insures maximum concentration of the time of sporozoite inoculation and throughout that portion of the incubation period in which presumably only pre-erythrocytic forms of the malarial parasite are present. Because the 8aminoquinolines disappear from the plasma within 24 hours after the last dose, and because extensive tissue accumulation does not occur (16), any effect produced may be assumed to be the result of action on pre-erythrocytic stages. The fact that pamaquin and three of its analogues exhibited prophylactic activity against vivax malaria when administration was limited to the prepatent period of the disease, suggests that these compounds possess the ability to inactivate or eradicate the sporozoites or hypothetical per-erythrocytic or tissue stages.

Four of the six subjects who developed primary attacks in spite of prophylactic treatment were then cured with drugs ordinarily ineffective in preventing relapse. In these subjects, the initial treatment with 8-aminoquinoline compounds may have altered the parasites sufficiently to render them unusually susceptible to subsequent therapy. Since the previous prophylactic treatment was stopped before the time when trophozoites appear in the untreated case, any effect was presumably exerted only on pre-erythrocytic stages of the parasite.

It is our opinion that $180 \mathrm{mgm}$. of pentaquine for eight days exceeds the maximum safe dose in man. Drug fever precludes the administration of $\mathrm{SN}-1,452$ at $240 \mathrm{mgm}$. a day. Pamaquin at 90 mgm. a day, SN-11,191 at $90 \mathrm{mgm}$. a day, and pentaquine at $120 \mathrm{mgm}$. a day also exceed the dosage tolerated by some white healthy subjects. Their clinical use in these amounts is dangerous.

The drugs studied have relatively high toxicity for man and are quickly degraded or metabolized so that they must be administered at frequent intervals. These qualities preclude the general use of these compounds as prophylactic agents, though one of the four (pentaquine) has been demonstrated to be highly effective in the radical cure of vivax malaria when administered with quinine in relatively non-toxic doses (17).

\section{CONCLUSIONS}

1. Using the Chesson strain, we have confirmed the finding of James, and of Feldman, Packer, et $a l$. , that pamaquin may act as a true prophylactic for sporozoite-induced Plasmodium vivax malaria. However, it did not protect all subjects under the conditions of this study.

2. Three other 6-methoxy-8-aminoquinoline compounds were at least equally effective as prophylactic agents when administered in a dosage approaching the maximum amount tolerated.

3. There was no positive correlation between plasma drug concentration and the prophylactic effect of these drugs.

4. In those subjects whose primary attacks were not prevented by prophylactic treatment, there is evidence that the disease was so altered by the prophylactic therapy that it was rendered susceptible to cure by drug regimes ordinarily ineffective in preventing relapse.

5. The results suggest that the compounds tested exert a deleterious effect upon pre-erythrocytic stages of the malarial parasite.

\section{BIBLIOGRAPHY}

1. James, S. P., Some general results of a study of induced malaria in England. Tr. Roy. Soc. Trop. Med. \& Hyg., 1931, 25, 477.

2. James, S. P., On the prevention of malaria with plasmoquine. Lancet, 1931, 2, 341.

3. James, S. P., The therapeutics of malaria. Third General Report of the Malaria Commission of the Health Organization of the League of Nations. Quart. Bull. Health Org. of League of Nations, 1933, 2, 185.

4. Fairley, N. H., Chemotherapeutic suppression and prophylaxis in malaria. Tr. Roy. Soc. Trop. \& Med. Hyg., 1945, 38, 311.

5. Malaria Commission of the League of Nations Health Organization, Fourth General Report, The treatment of malaria (Study of synthetic drugs, as compared with quinine, in the therapeutics and prophylaxis of malaria). Bull. of Health Org. of League of Nations, 1937, 6, 895.

6. Dieuaide, F. R., Clinical malaria in wartime. War Med., 1945, 7, 7.

7. Feldman, H. R., Packer, H., Murphy, F. D., and Watson, R. B., Pamaquine naphthoate as a prophylactic for malarial infections. Fed. Proc., 1946, $5,244$.

8. Schmidt, L. H., Smith, C. C., Hughes, H. B., and Carter, C., Studies on the 8-aminoquinolines. 1. The toxicities of pamaquine and plasmocid in different animal species. Fed. Proc., 1947, 6, 369.

9. Alving, A. S., Craige, B., Jr., Pullman, T. N., Whorton, C. M., Jones, R., Jr., and Eichelberger, L., 
Procedures used at Stateville Penitentiary for the testing of potential antimalarial agents. J. Clin. Invest., 1948, 27, Suppl., 2.

10. Ehrman, F. C., Ellis, J. M., and Young, M. D., Plasmodium vivax, Chesson strain. Science, 1945, 101, 377.

11. Coatney, G. R., Cooper, W. C., Ruhe, D. S., and Young, M. D., Studies in human malaria. XVII. Trials of quinacrine, colchicine $(\mathrm{SN}-12,080)$ and quinine against Chesson strain vivax malaria. Am. J. Hyg., to be published.

12. Craige, B., Jr., Alving, A. S., Jones, R., Jr., Whorton, C. M., Pullman, T. N., and Eichelberger, L., The Chesson strain of Plasmodium vivax malaria. II. Relationship between prepatent period, latent period, and relapse rate. J. Infect. Dis., 1947, 80, 228.

13. Brodie, B. B., Udenfriend, S., and Taggart, J. V.,
Analysis of basic organic compounds in biological tissues. 4. Coupling with diazonium salts. Fed. Proc., 1946, 5, 125.

14. Wendel, W. B., Personal communication.

15. Craige, B., Jr., Eichelberger, L., Jones, R., Jr., Pullman, T. N., Alving, A. S., and Whorton, C. M., The toxicity of large doses of pentaquine (SN$13,276)$ a new antimalarial drug. J. Clin. Invest., 1948, 27, Suppl., 17.

16. Schmidt, L. H., Personal communication.

17. Alving, A. S., Craige, B., Jr., Jones, R., Jr., Whorton, C. M., Pullman, T. N., and Eichelberger, L., Pentaquine $(\mathrm{SN}-13,276)$ a therapeutic agent effective in reducing the relapse rate in vivax malaria. J. Clin. Invest., 1948, 27, Suppl., 25.

18. Wiselogle, F. Y., editor, A Survey of Antimalarial Drugs, 1941-1945. Edwards Brothers, Inc., Ann Arbor, 1946. 